Research article

Open Access

\title{
Influence of Piperine on Transcutaneous Permeation of Repaglinide in Rats and on Tight Junction Proteins in HaCaT Cells: Unveiling the Mechanisms for Enhanced Permeation
}

\author{
Neeraj Kaushal ${ }^{1}$, Subheet Jain ${ }^{1}$, Paturu Kondalah ${ }^{2}$, Ashok K. Tiwary * 1 \\ ${ }_{1}^{1}$ Department of Pharmaceutical Sciences and Drug Research, Punjabi University, Patiala-147002, India. \\ ${ }^{2}$ Department of Molecular Reproduction, Development and Genetics, Indian Institute of Science, Bangalore- \\ 560012. India.
}

* Corresponding author. E-mail: aktiwary2@rediffmail.com (A. K. Tiwary)

Sci Pharm. 2009; 77: 877-897

doi:10.3797/scipharm.0907-06

Published: $\quad$ September $27^{\text {th }} 2009$

Accepted: September $24^{\text {th }} 2009$

Received: July $7^{\text {th }} 2009$

This article is available from: http://dx.doi.org/10.3797/scipharm.0907-06

(C) Kaushal et al.; licensee Österreichische Apotheker-Verlagsgesellschaft m. b. H., Vienna, Austria.

This is an Open Access article distributed under the terms of the Creative Commons Attribution License (http://creativecommons.org/licenses/by/3.0/), which permits unrestricted use, distribution, and reproduction in any medium, provided the original work is properly cited.

\begin{abstract}
The purpose of this study was to evaluate the influence of piperine on permeation of repaglinide (RGE) across rat epidermis. In addition, the role of chitosan (CTN) and its combination with piperine was investigated for exploring the possibility of further enhancing the permeation of RGE. The permeation of RGE across excised rat epidermis was, respectively, $\sim 4$-fold, $\sim 5$-fold and $\sim 6$ fold higher when piperine $(0.008 \% \mathrm{w} / \mathrm{v})$, CTN $(1 \% \mathrm{w} / \mathrm{v})$, or piperine - CTN mixture was used as donor vehicle as compared to propylene glycol: ethanol (PG: EtOH) (7:3) mixture. The merger of T2 and T3 (lipid-specific) and obliteration of T4 (protein-specific) endothermic transitions in the thermograms of excised rat epidermis suggested overwhelming influence of these treatments on skin lipids and proteins. Further, the observed increase in intercellular space, disordering of lipid structure and corneocyte detachment indicated considerable effect on the ultrastructure of rat epidermis. The enhancement in permeation of RGE across rat epidermis excised after various treatments for different periods was correlated with the transepidermal water loss of similarly treated viable rat skin. The treatment of HaCaT cell line with piperine influenced the TJ plaque protein zonula occludens (ZO-1) as evidenced by reduced immunofluorescence of anti-TJP1 (ZO-1) antibody in confocal laser scanning microscopic studies. Treatment of $\mathrm{HaCaT}$ cells with CTN decreased the intensity of fluorescence on
\end{abstract}


the cell walls only marginally. However, remarkable decrease in the immunofluorescence of anti-TJP1 (ZO-1) antibody was observed after treatment of HaCaT cells with mixture of piperine and CTN. The systemic delivery of RGE in rats was enhanced by 8-fold and 9.5-fold from transdermal formulations containing, respectively, piperine $(0.008 \% \mathrm{w} / \mathrm{v})$ or piperine $(0.008 \% \mathrm{w} / \mathrm{v})-\mathrm{CTN}$ $(1 \% \mathrm{w} / \mathrm{v})$ mixture as enhancer. Overall, the observations suggested overwhelming influence of piperine and CTN on ZO-1 protein to be responsible for enhancing the percutaneous permeation of RGE.

\section{Keywords}

Repaglinide $\cdot$ Piperine $\cdot$ Percutaneous permeation • Transepidermal water loss • Scanning and transmission electron microscopy

\section{Introduction}

Repaglinide (RGE) is an antidiabetic drug. It has an extremely short half life of $1 \mathrm{hr}$. In addition, the oral bioavailability of RGE is low (56-63\%) due to extensive hepatic first pass effect [1]. These properties of RGE make it a suitable candidate for transdermal delivery. The need for transdermal delivery of RGE is further justified due to the requirement of maintaining unfluctuating plasma concentrations for effective management of blood sugar for long period in diabetic patients. However, the literature does not reveal any transdermal patch of RGE approved for human use. This may be due to the excellent impervious nature of skin, which is the major impediment in the successful transcutaneous passage of almost all drugs. Although, enormous work has been done for enhancing the transcutaneous permeation of drugs, the most convenient approach pertains to inclusion of chemicals that perturb the skin temporarily. Most of the synthetic chemicals used for this purpose do not allow the skin to return to normal condition for very long duration [2] and often get transported into the systemic circulation [3]. It is for these reasons that the quest for safe and effective percutaneous permeation enhancers continues. Herbal enhancers are comparatively safer and hence, possess great potential for use in transdermal formulation.

Piperine is a vanilloid obtained from plants belonging to the Piperaceae family. It is routinely consumed as a dietary spice by the people around the world and enjoys GRAS status by US FDA. Piperine is reported to enhance the bioavailability of various structurally and therapeutically diverse drugs like phenytoin [4] propranolol and theophylline [5]. This action was attributed to the alteration of lipid conformation and fluidization of intestinal membrane [6]. Further, piperine, like capsaicin, is reported to produce agonist activity at the human vanilloid receptor (TRPV1) yielding rapidly activating whole cell currents [7]. The activation of TRPV1 receptor is reported to enhance the intestinal absorption in human beings $[8,9]$. The fact that these receptors are also expressed in the human skin [10], makes it logical to evaluate the role of piperine in enhancing the percutaneous permeation of RGE.

The tight junctions (TJ) of Caco-2 cells are reported to be influenced by chitosan (CTN) due to structural reorganization of the TJ proteins zona occludin (ZO-1) and occludin $[11,12]$. TJs are dynamic structures with multi-protein complexes consisting of trans- 
membrane proteins (claudins, occludin, junctional adhesion molecules) and TJ plaque proteins (ZO-1, ZO-2, ZO-3, cingulin, symplekin). TJs serve both as a fence between apical and basolateral membrane domains and as a selective permeability barrier in the paracellular space between adjacent epithelial and endothelial cells. TJ proteins (claudins, occludin and ZO-1) are also reported to be expressed in stratum granulosum in human epidermis [13]. Therefore, treatment of HaCaT cells or epidermis with CTN can be hypothesized to modulate the TJ-mediated permeation of molecules. In view of the effect of piperine on TRPV1 receptor and that of CTN on TJ proteins, a potentiation in percutaneous permeation of RGE could be expected by using their combination.

In the light of the above, the present investigation was designed to evaluate the feasibility of using piperine and /or CTN for enhancing the transdermal delivery of RGE. Further, their effect on the ultrastructural manifestations, thermotropic behavior and transepidermal water loss across rat skin was investigated. In addition, the effect on TJ protein (ZO-1) of $\mathrm{HaCaT}$ cell line was undertaken in an attempt to unveil their mechanism of percutaneous permeation enhancement.

\section{Results and Discussion}

\section{Charaterization of piperine}

The crystals of piperine obtained by recrystallization in alcoholic $\mathrm{KOH} \mathrm{(10 \% )} \mathrm{solution} \mathrm{were}$ compressed into pellet with $\mathrm{KBr}$ and subjected to IR analysis. The characteristic peaks obtained in the IR spectra are summarized in Table 1. The IR spectrum was similar to that reported by Ikan [14]. Further, HPTLC analysis using toluene:diethylacetate (7:3) as mobile phase gave a single band at $340 \mathrm{~nm}$ with $\mathrm{Rf}$ value of 0.33 . The amount of piperine was calculated to be $6.172 \% \mathrm{w} / \mathrm{w}$.

Tab. 1. IR analysis of piperine in piper nigrum

\begin{tabular}{ll} 
Wave number $\left(\mathbf{c m}^{-1}\right)$ & Assignment \\
\hline 3008.5 & C-H streching (Aromatic) \\
$2939.7,2861.3$ & C-H streching (Aliphatic) \\
1633.8 & C=O streching \\
$1611.8,1583.6,1510.1$ & C=C streching (Aromatic) \\
$1252.5,1193.7$ & $=$ C-O-C asymmetrical stretching \\
1031.6 & =C-O-C symmetrical stretching \\
\hline
\end{tabular}

\section{In vitro permeation of RGE across rat epidermis}

The amount of RGE permeated in the receptor fluid was analyzed at $243 \mathrm{~nm}$ spectrophotometrically (Beckman, USA, DU 640B). The receptor fluid contained sodium azide $(0.05 \% \mathrm{w} / \mathrm{v})$ for preventing the epidermal sheet from microbial attack [15] and polyethylene glycol (PEG) $400(10 \% \mathrm{v} / \mathrm{v})$ as solubilizing agent for maintaining sink condition in the receptor compartment. The UV spectra of sodium azide or PEG 400 (without RGE) were obtained for confirming that they did not interfere with the estimation of RGE. It was found that sodium azide or PEG 400 yielded absorbance peaks, respectively, in the range of $200-220 \mathrm{~nm}$ and $200-230 \mathrm{~nm}$. These absorbance peaks were 
observed to reduce significantly in the presence of low concentrations of RGE and were totally absent in the presence of moderate concentrations of RGE. Therefore, the standard plot of RGE was prepared in presence of sodium azide $(0.05 \% \mathrm{w} / \mathrm{v})$ and PEG $400(10 \%$ $\mathrm{v} / \mathrm{v})$. The standard plot was linear from $5-80 \mu \mathrm{g} / \mathrm{ml}$ and yielded the equation $\mathrm{Y}=0.0162 \mathrm{x}+$ 0.035 with $r^{2}$ value of 0.9996

Piperine $(0.008 \% \mathrm{w} / \mathrm{v})$ enhanced the permeation of RGE across excised rat epidermis 4fold as compared to the donor vehicle (PG: EtOH, 7:3). However, increasing the concentration of piperine to $0.01 \% \mathrm{w} / \mathrm{v}$ did not further enhance the permeation of RGE. This observation is in consonance with the findings of Suresh [16] who reported decreased transportation of piperine across everted rat intestine in the presence of greater than $0.008 \% \mathrm{w} / \mathrm{v}$ concentration of piperine and ascribed it to the reduction in solubility of piperine in Krebs-Ringer phosphate buffer. Piperine is reported to posses the ability to modulate membrane dynamics due to its lipid solubility that is known to allow its interaction with lipids and hydrophobic domains in the vicinity of epidermal proteins. These effects are reported to decrease the tendency of membrane lipids to act as stearic constrains. The ability of piperine to modulate the permeability characteristics of intestine by inducing alterations in membrane dynamics, brush border fluidity is reported [6]. Although, these reasons cannot be directly held responsible for the observed permeation enhancement in skin, they do indicate the capability of piperine to perturb the microenvironment of epidermis. This was evident from the alterations observed in the ultrastructural features (Fig. 1) as well as merger of lipid specific endotherms (Fig. 2). These observations are discussed in the subsequent sections.

The use of CTN $(1 \% \mathrm{w} / \mathrm{v})$ was observed to enhance the permeation of RGE across excised rat epidermis by $\sim 5$-fold as compared to the control (acetate buffer, pH 6.0). CTN is known to possess high cationic charge due to which it has been reported to disturb the integrity of skin lipids and open the tight junctions responsible for maintainance of barrier status of the skin [17]. The enhanced in vitro permeation of RGE in the presence of CTN could be ascribed to the perturbation of epidermal microconstituents. The perturbation by CTN was observed to produce pores in the epidermal sheets (Fig. 1). The epidermal lipids (Fig. 2) too were adversely affected as evidenced in the thermograms.

It was anticipated that the combination of piperine and CTN would potentiate the permeation of RGE because the reports of the former suggested its influence on TRPV1 receptors [7] while the later was reported to affect the tight junctions [18, 19]. However, the combination of piperine $(0.008 \% \mathrm{w} / \mathrm{v})$ and CTN $(1 \% \mathrm{w} / \mathrm{v})$ only marginally enhanced the permeation of RGE by $\sim 1.18$-fold or $\sim 1.6$-fold as compared to, respectively, CTN or piperine alone (Table 2). These results indicated that combining piperine with CTN did not potentiate the permeation of RGE as compared to CTN. The slightly higher enhancement in the permeation of RGE ( 1.6-fold) in the presence of piperine-CTN mixture suggested its better performance as compared to that of piperine alone. It is worthy to note that the piperine-CTN mixture was significantly more effective than piperine $(p<0.05)$ across viable rat skin as compared to excised skin in enhancing the transcutaneous delivery of RPG. The reasons for the observed better rate and extent of RGE permeation across viable skin are discussed later in the section on pharmacokinetic evaluation of the transdermal patches. The better performance of the combination in viable skin could possibly be due to the action of piperine on TRPV1 receptors that shall not be active in excised skin. Furthermore, the inherently higher permeation of lipophilic drugs across 
viable skin [20] could have also contributed to the better performance of piperine-CTN combination in enhancing the permeation of RGE across viable skin. Nevertheless, both piperine and CTN can be suggested to influence the lipids and ultrastructure of rat epidermis.

Tab. 2. In vitro permeation of RGE from different formulations across excised rat epidermis.

\begin{tabular}{|c|c|c|}
\hline Treatment & $\begin{array}{l}\text { RGE Flux } \\
\left(\mu \mathrm{g} / \mathrm{cm}^{2} / \mathrm{h}\right)^{\mathrm{a}}\end{array}$ & $\begin{array}{l}\text { Enhancement } \\
\text { ratio }\end{array}$ \\
\hline PG:ETOH(7:3) & $08.890 \pm 0.78$ & - \\
\hline Acetate buffer pH 6 & $09.658 \pm 0.37$ & - \\
\hline Piperine $(0.002 \% \mathrm{w} / \mathrm{v})$ & $16.039 \pm 0.93$ & $1.803^{\#}$ \\
\hline Piperine $(0.004 \% w / v)$ & $18.134 \pm 0.86$ & $2.039^{\#}$ \\
\hline Piperine $(0.006 \% \mathrm{w} / \mathrm{v})$ & $19.959 \pm 1.09$ & $2.244^{\#}$ \\
\hline Piperine $(0.008 \% \mathrm{w} / \mathrm{v})$ & $33.965 \pm 0.89$ & $3.818^{\#}$ \\
\hline Piperine $(0.01 \%$ w/v) & $24.815 \pm 0.98$ & $2.790^{\#}$ \\
\hline CTN $(1 \% \mathrm{w} / \mathrm{v})$ & $49.632 \pm 0.67$ & $5.138^{*}$ \\
\hline $\begin{array}{l}\text { Piperine + CTN } \\
(0.008 \% \mathrm{w} / \mathrm{v}+1 \% \mathrm{w} / \mathrm{v})\end{array}$ & $58.734 \pm 0.87$ & $6.081^{*}$ \\
\hline
\end{tabular}

\section{Electron microscopic studies}

Scanning electron microscopic (SEM) studies revealed loosening of stratum corneum (SC) surface layers by piperine (Fig. 1B) and creation of pores by CTN (Fig. 1D). Piperine-CTN mixture resulted in formation of largest pores coupled with loosening of SC surface (Fig.1C). The effect was of apparently less intensity when these formulations were applied to viable skin (Fig. 1E). The transmission electron microscopic (TEM) studies also revealed disordering of lipid areas and increase in intercellular space along with corneocyte detachment after treatment of excised skin containing piperine (Fig 1G), CTN (Fig. 1I) or mixture containing piperine-CTN mixture (Fig. 1H). These effects were apparently less severe when the treatments were given to viable skin (Fig. 1J). The less severe influence of these treatments on ultrastructural features of viable skin could be ascribed to the continuous attempt of the skin to restore its barrier status to normal level. 


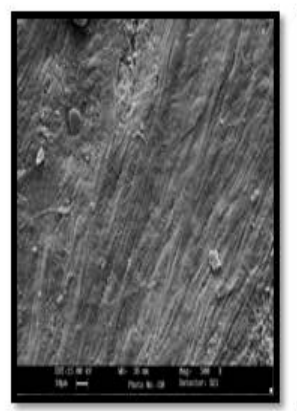

A

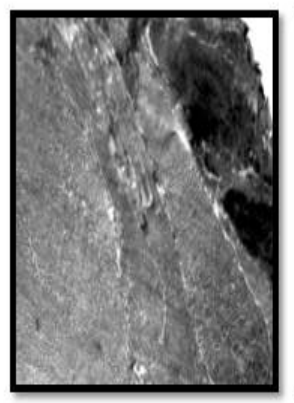

$\mathbf{F}$

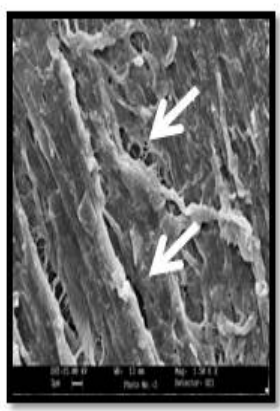

B

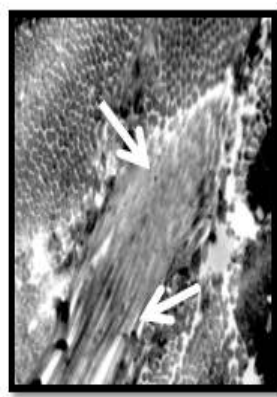

G

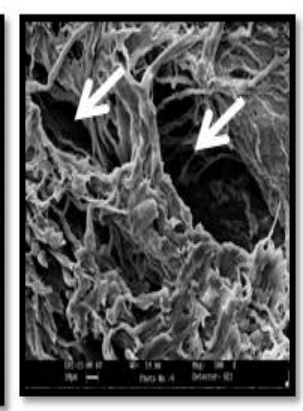

C

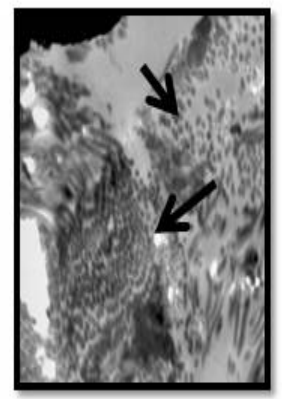

H

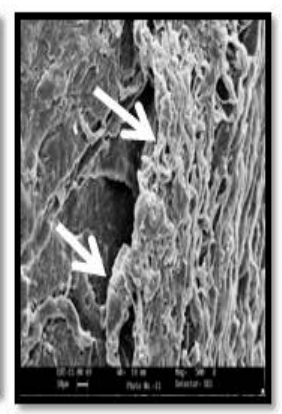

D

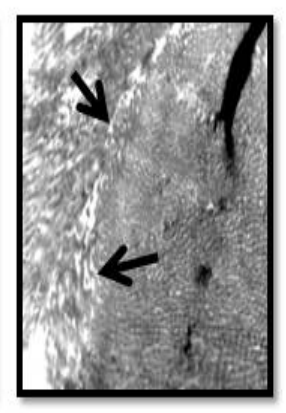

I

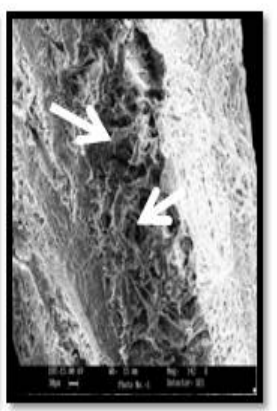

$\mathbf{E}$

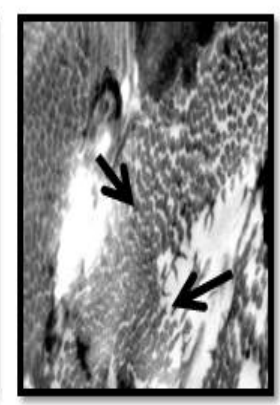

J

Fig. 1. Scanning electron and Transmission electron photomicrographs of rat skin: untreated epidermis ( $\mathrm{A}$ and $\mathrm{F}$ ); excised skin treated for: $36 \mathrm{hr}$ with $0.008 \% \mathrm{w} / \mathrm{v}$ piperine (B and $\mathrm{G})$; piperine-CTN mixture $(\mathrm{C}$ and $\mathrm{H}) ; 12 \mathrm{hr}$ with $1 \% \mathrm{w} / \mathrm{v}$ CTN (D and I) as well as viable skin treated for $36 \mathrm{hr}$ with piperine-CTN mixture (E and $\mathrm{J})$.

[Arrows indicate creation of surface pores (SEM) or disruption of corneocytes and lipids (TEM)].

\section{Thermotropic attributes of rat epidermis after treatment}

Fig. 2. depicts the DSC thermograms of rat epidermis after various treatments. The normal (untreated) epidermis (Fig. 2A) exhibited three endothermic transitions each at $70^{\circ} \mathrm{C}$ (T2), $80^{\circ} \mathrm{C}$ (T3), and $97^{\circ} \mathrm{C}(\mathrm{T} 4)$. Treatment with PG: $\mathrm{EtOH}(7: 3)$ mixture obliterated the T4 endotherm while the T2 and T3 endotherms specific for lipids were not significantly effected (Fig. 2B). The absence of T4 endotherm (indicative of protein component of skin) [21] after treatment with PG:EtOH (7:3) solution containing piperine suggested the influence of piperine on epidermal protein component (Figs. 2C-E). In addition, decrease in the enthalpy accompanied with slight shifting of $\mathrm{Tm}$ to higher temperature of $\mathrm{T} 2$ transition was observed after treatment of excised epidermis with any dose of piperine (Table 3). The broad nature of endotherm and shifting of Tm towards higher temperature could be attributed to the merger of T2 and T3 transitions. This suggested the effect of piperine on epidermal lipids as well. CTN treatment of excised rat epidermis was also observed to result in merger of T2 and T3 endotherms (Fig. 2F). Similarly, treatment with piperine-CTN mixture resulted in merger of T2 and T3 endotherms as well as obliteration of T4 endotherm. Therefore, the observed findings of merger of T2 and T3 endotherms coupled with obliteration of T4 endotherm after treatment with piperine, CTN or piperine-CTN mixture suggested their influence on both epidermal lipids and proteins of excised rat epidermis. 


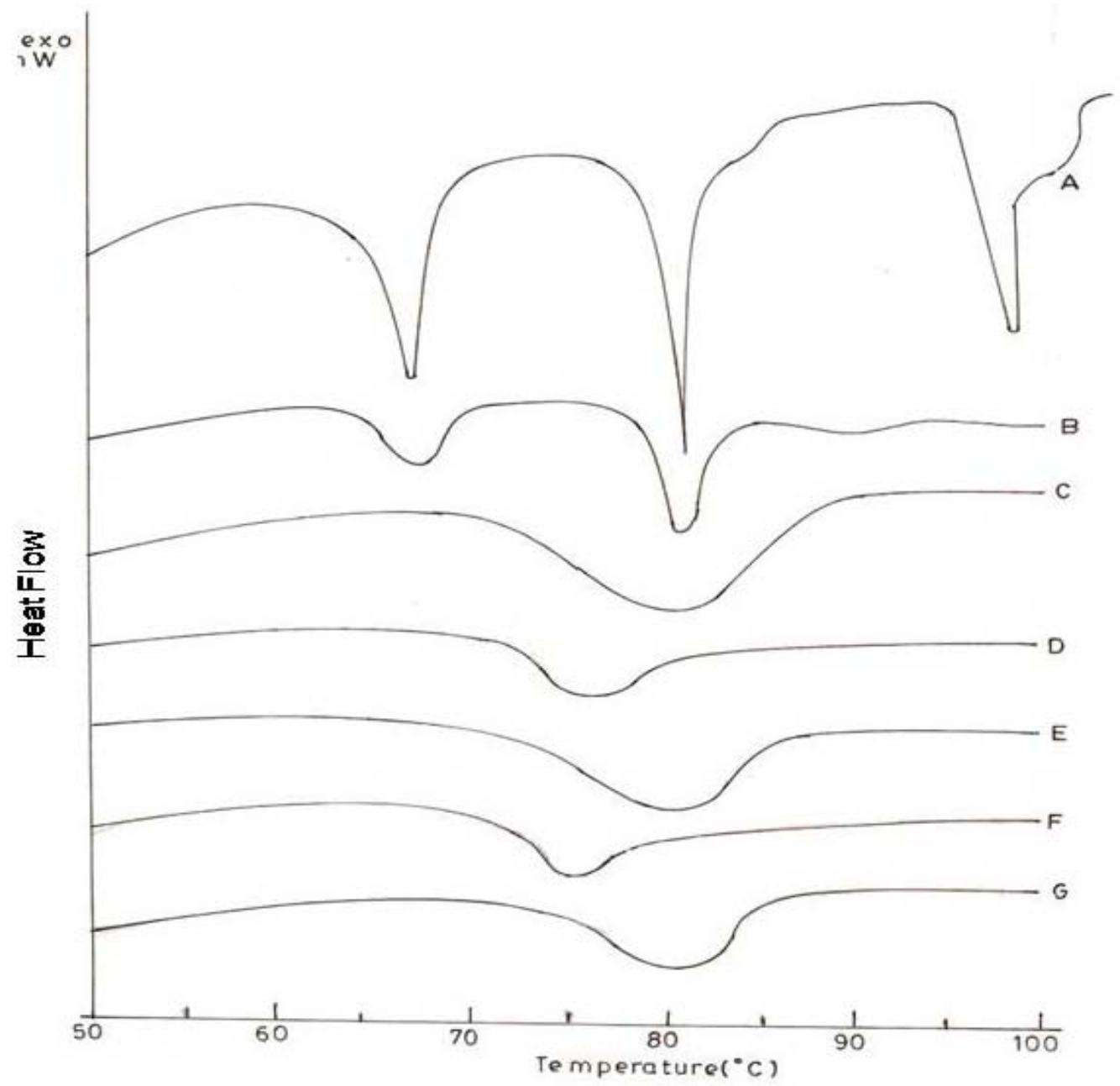

Fig. 2. DSC thermograms of normal rat epidermis $(A)$; and after treatment with $P G$ : EtOH (B), piperine $(0.004 \% \mathrm{w} / \mathrm{v})(\mathrm{C})$, piperine $(0.008 \% \mathrm{w} / \mathrm{v})(\mathrm{D})$; Piperine $(0.01 \% \mathrm{w} / \mathrm{v})(\mathrm{E}), \mathrm{CTN} 1 \% \mathrm{w} / \mathrm{v}(\mathrm{F})$; piperine $(0.008 \% \mathrm{w} / \mathrm{v})-\mathrm{CTN}(1 \% \mathrm{w} / \mathrm{v})$ mixture (G).

Tab. 3. Thermotropic parameters of excised rat epidermis after various treatments

\section{Treatment}

Piperine $(0.004 \% \mathrm{w} / \mathrm{v})$

Piperine $(0.008 \% \mathrm{w} / \mathrm{v})$

Piperine $(0.01 \% \mathrm{w} / \mathrm{v})$

CTN $(1 \% \mathrm{w} / \mathrm{v})$

Piperine

$(0.008 \% \mathrm{w} / \mathrm{v}+\mathrm{CTN}(1 \% \mathrm{w} / \mathrm{v})$

\begin{tabular}{lll}
\multicolumn{2}{c}{ Endothermic transition T2 ${ }^{\mathrm{a}}$} & $\operatorname{Tm~}\left({ }^{\circ} \mathbf{C}\right)$ \\
\cline { 1 - 2 } $\boldsymbol{\Delta} \mathbf{H}\left(\mathbf{J g}^{-1}\right)$ & $\boldsymbol{\Delta H}$ Decrease $(\%)$ & \\
\hline $38.83 \pm 0.59$ & - & 69.25 \\
$21.24 \pm 0.14$ & $45.03 \pm 0.24$ & 80.76 \\
$15.34 \pm 0.25$ & $60.49 \pm 0.74$ & 75.32 \\
$18.47 \pm 0.56$ & $52.43 \pm 0.81$ & 77.21 \\
$17.08 \pm 0.28$ & $56 \pm 0.47$ & 73.04 \\
$19.44 \pm 0.18$ & $49.89 \pm 0.25$ & 79.13
\end{tabular}




\section{Solubility and partition coefficient of RGE}

The aqueous solubility of RGE in PB was observed to increase 70-fold in the presence of $0.008 \% \mathrm{w} / \mathrm{v}$ piperine (Table 4). However, further increase in the solubility of RGE was not observed when piperine was used in concentrations greater than $0.008 \% \mathrm{w} / \mathrm{v}$. This seems to be due to reduction in the solubility of piperine at concentrations greater than $0.008 \%$ $\mathrm{w} / \mathrm{v}$. The observations of McNamara [7] who reported difficulty in examining the effect of concentrations of piperine greater than $0.008 \% \mathrm{w} / \mathrm{v}$ on human vanilloid receptors due to its reduced solubility in the extracellular fluid supports this view point. The observed maximum absorption of piperine when present in the concentration range of $0.002 \%$ to $0.01 \% \mathrm{w} / \mathrm{v}$ further proves this contention [16].

It is important to note that although, the $\mathrm{K}_{\mathrm{IPM} / \mathrm{PB}}$ of RGE decreased in presence of piperine due to increase in its aqueous solubility, the in vitro permeation of RGE was 4-fold higher than the control as shown in Table 2. RGE is a lipophilic molecule. The increase in its aqueous solubility in the presence of piperine $(0.008 \% \mathrm{w} / \mathrm{v})$ can be postulated to have contributed to its enhanced passage through the paracellular route, which is reported to be influenced by piperine. The enhancement in permeation of lipophilic molecules tiludronate by sodium lauryl sulphate and cosalane by sodium desoxycholate and HP-betacyclodextrin due to opening of paracellular pathway in the human Caco-2 cell line [22, 23] supports this contention. Therefore, RGE permeation could not be suggested to be a simple manifestation of its solubility modulation by piperine. The high cationic charge possessed by CTN [18] and its ability to interact with skin lipids [24] as well as the reported interaction of piperine with TRPV1 receptor [7] made it logical to investigate their influence on ZO-1 (TJ protein) of HaCaT cells and ultrastructural features of rat skin for gaining an insight into exact mechanisms operative in permeation enhancement of RGE.

Tab. 4. Solubility and Partition coefficient of RGE in PB in presence of different concentrations of piperine.

\begin{tabular}{lll}
\hline Vehicle & Solubility $(\mu \mathrm{g} / \mathrm{ml})^{\mathrm{a}}$ & $\mathrm{K}_{\text {IPM/PB }}$ \\
\hline Phosphate Buffer $\mathrm{pH} 7.4$ & $0.3185 \pm 0.221$ & 15.696 \\
Phosphate Buffer $(0.05 \%$ & $1.7012 \pm 0.456$ & 25.939 \\
w/v sodium azide, $10 \% \mathrm{v} / \mathrm{v}$ & & \\
PEG) & & \\
Piperine $(0.004 \% \mathrm{w} / \mathrm{v})$ & $62.306 \pm 0.264$ & 11.473 \\
Piperine $(0.008 \% \mathrm{w} / \mathrm{v})$ & $118.56 \pm 0.563$ & 13.436 \\
Piperine $(0.01 \% \mathrm{w} / \mathrm{v})$ & $107.16 \pm 0.731$ & 12.122 \\
\hline${ }^{\mathrm{a}}$ Mean \pm S.D of three experiments & &
\end{tabular}




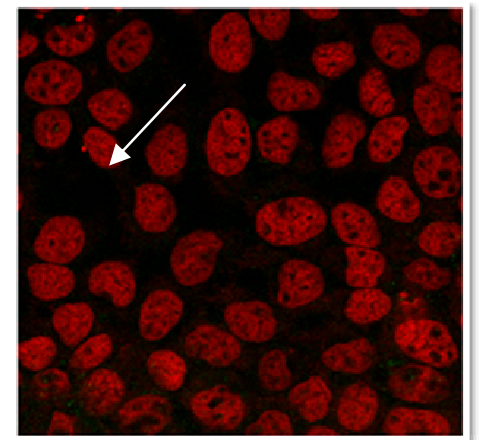

A

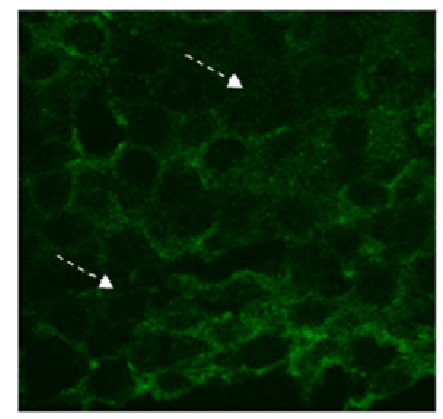

D

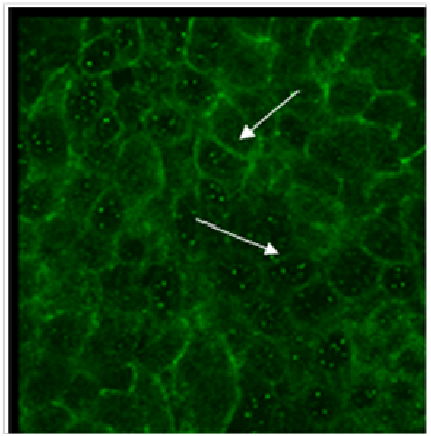

B

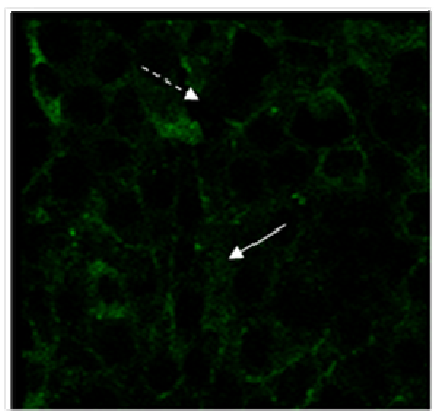

E

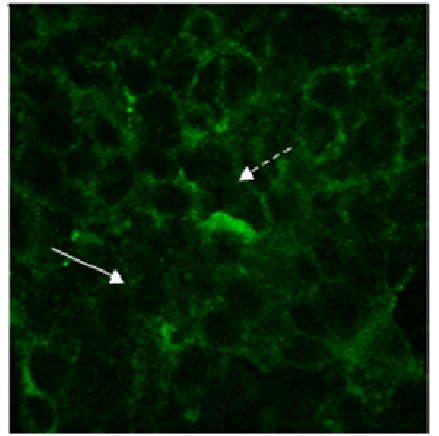

C

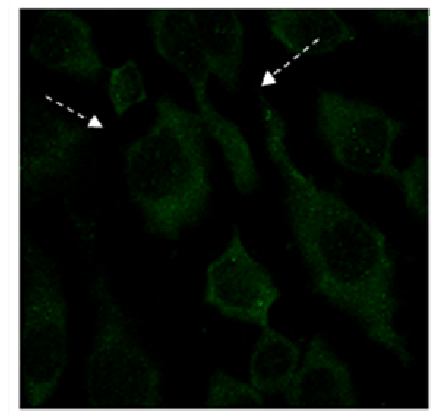

$\mathbf{F}$

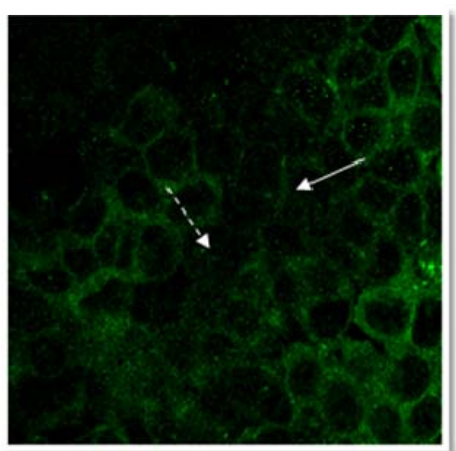

G

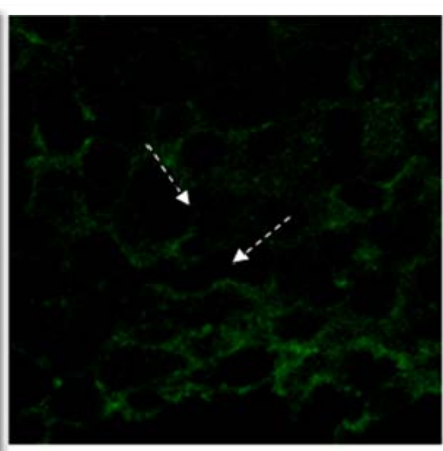

H

Fig. 3. Confocal laser scanning photomicrographs of $\mathrm{HaCaT}$ cells: without treatment with antibodies (A); after treatment with antibodies only (B); after treatment with piperine $(0.002 \% \mathrm{w} / \mathrm{v})(\mathrm{C})$; piperine $(0.004 \% \mathrm{w} / \mathrm{v})(\mathrm{D})$; piperine $(0.008 \% \mathrm{w} / \mathrm{v})(\mathrm{E})$; piperine $(0.016 \% \mathrm{w} / \mathrm{v})(\mathrm{F})$; CTN $(1 \% \mathrm{w} / \mathrm{v})(\mathrm{G})$; piperine $(0.008 \% \mathrm{w} / \mathrm{v})-\mathrm{CTN}(1 \%$ $w / v)$ mixture $(H)$.

[Propidium iodide (PI) stained red colored nucleus (A); Fluorescence due to attachment of primary anti-TJP1 (ZO-1) antibody labeled with FITC-conjugated anti rabbit IgG antibody indicates presence of ZO-1 protein in cell boundaries (B-H). The solid arrows indicate presence of demarcating cell boundaries and broken arrows indicate disruption of demarcating cell boundaries].

\section{Confocal laser Scanning microscopy}

TJs are characterized as the fusion of contiguous cell membranes located in the apical side. There are many molecular components of the TJ, such as occludin, claudins, JAM, $\mathrm{ZO}$, and actin. Among these components, the $\mathrm{ZO}$ is known to play a major role in controlling the paracellular permeability. Interfering with the junctional complex allows the 
cells to separate and thus pull apart the TJ to open the barrier [25]. Therefore, ZO staining was performed to visualize the effect of piperine on the TJ of HaCaT cells. In addition, the distribution of TJ-associated protein ZO-1 in the HaCaT cells was examined because the increase in epithelial TJ permeability is reported to be associated with changes in the distribution of TJ proteins. Staining of the HaCaT cells with propidium iodide (PI) without treatment with antibodies resulted in red color staining of the nucleus (Fig. 3A). Treatment with primary anti-TJP1 (ZO-1) antibody labeled with FITC-conjugated anti rabbit IgG was observed to exhibit continuous staining specifically of cell borders indicating the presence of ZO-1 protein in TJs of HaCaT cells (Fig. 3B). Figure 3C shows the effect of $0.002 \% \mathrm{w} / \mathrm{v}$ piperine on HaCaT cells. A decrease in the intensity of immunofluorescence as compared to the untreated cells is evident. Increasing the concentration of piperine to $0.004 \% \mathrm{w} / \mathrm{v}$ was found to further decrease the immunofluorescence of HaCaT cells (Fig. 3D). The cells were observed to become elongated and diffused immunofluorescence was observed when HaCaT cells were treated with $0.008 \% \mathrm{w} / \mathrm{v}$ piperine (Fig. 3E). At higher concentration of $0.016 \% \mathrm{w} / \mathrm{v}$, piperine was observed to produce separation of cells. The immuofluorescence was markedly diffused along the cell borders with no demarcation of cell boundaries (Fig. 3F), indicating considerable damage to the cell organization. Fig. 3G depicts the influence of CTN $(1 \% \mathrm{w} / \mathrm{v})$ on ZO-1 protein of HaCaT cells. Less severe effect of CTN (Fig. 3G) as compared to piperine (Fig. 3E) on ZO-1 protein of HaCaT cells was observed. The mixture of piperine $(0.008 \% \mathrm{w} / \mathrm{v})-\mathrm{CTN}(1 \% \mathrm{w} / \mathrm{v})$ was observed to remarkably decrease the intensity of immunofluorescence of anti-TJP1 (ZO-1) antibody. The absence of fluorescence at many places along the cell boundaries indicated considerable disorganization of ZO-1 TJ proteins of HaCaT cells by the combination of piperine-CTN mixture (Fig. 3H). Overall, these studies indicated most severe effect of piperine-CTN mixture (Fig. $3 \mathrm{H}$ ) followed by $0.008 \% \mathrm{w} / \mathrm{v}$ piperine (Fig. 3E) and $1 \% \mathrm{w} / \mathrm{v}$ CTN (Fig. 3G). Therefore, the findings of CLSM studies strongly implicated the ZO-1 TJ protein in influencing the permeation of RGE by piperine, CTN or their combination.

\section{Transepidermal water loss (TEWL) studies}

An increase in TEWL is known to accompany skin perturbation by oleic acid, propylene glycol [26], diethylene glycol monoethyl ether [27] and chitosan polyelectrolyte complexes [28]. The TEWL of viable rat skin portions was observed to increase till $36 \mathrm{hr}$ of treatment with piperine $(0.008 \% \mathrm{w} / \mathrm{v})$ or piperine $(0.008 \% \mathrm{w} / \mathrm{v})-\mathrm{CTN}(1 \% \mathrm{w} / \mathrm{v})$ mixture and till $12 \mathrm{hr}$ of treatment with CTN $(1 \% \mathrm{w} / \mathrm{v})$. The in vitro permeation of RGE across epidermal sheets excised after these treatments also followed the same trend as TEWL (Fig. 4). The rise in TEWL was very slow after treatment with CTN $(1 \% \mathrm{w} / \mathrm{v})$ and the maximum value observed was significantly $(p<0.05)$ lower as compared to that obtained after treatment with piperine-CTN mixture. Further, the TEWL was observed to decrease continuously after 36 $\mathrm{hr}$ of treatment with piperine or piperine-CTN mixture or after $12 \mathrm{hr}$ of treatment with CTN. It is evident from Fig. 4 that the TEWL of skin treated with CTN returned to normal with in $48 \mathrm{hr}$. Although, the TEWL of skin treated with piperine or piperine-CTN mixture did not return to the basal level with in $36 \mathrm{hr}$, a sharp decrease after $36 \mathrm{hr}$ was clearly evident. The weaning off of the effect after $48 \mathrm{hr}$ of treatment could be attributed to the recovery of barrier status of skin as a natural response phenomenon in a bid to restore its original condition. The perturbation of skin is reported to induce enhanced synthesis of triglycerides, cholesterol and ceramides [29]. This results in restoration of the barrier status of skin over a period of time. The results of these studies strongly indicated a correlation between perturbation of skin with the enhanced permeation of RGE across rat skin. 


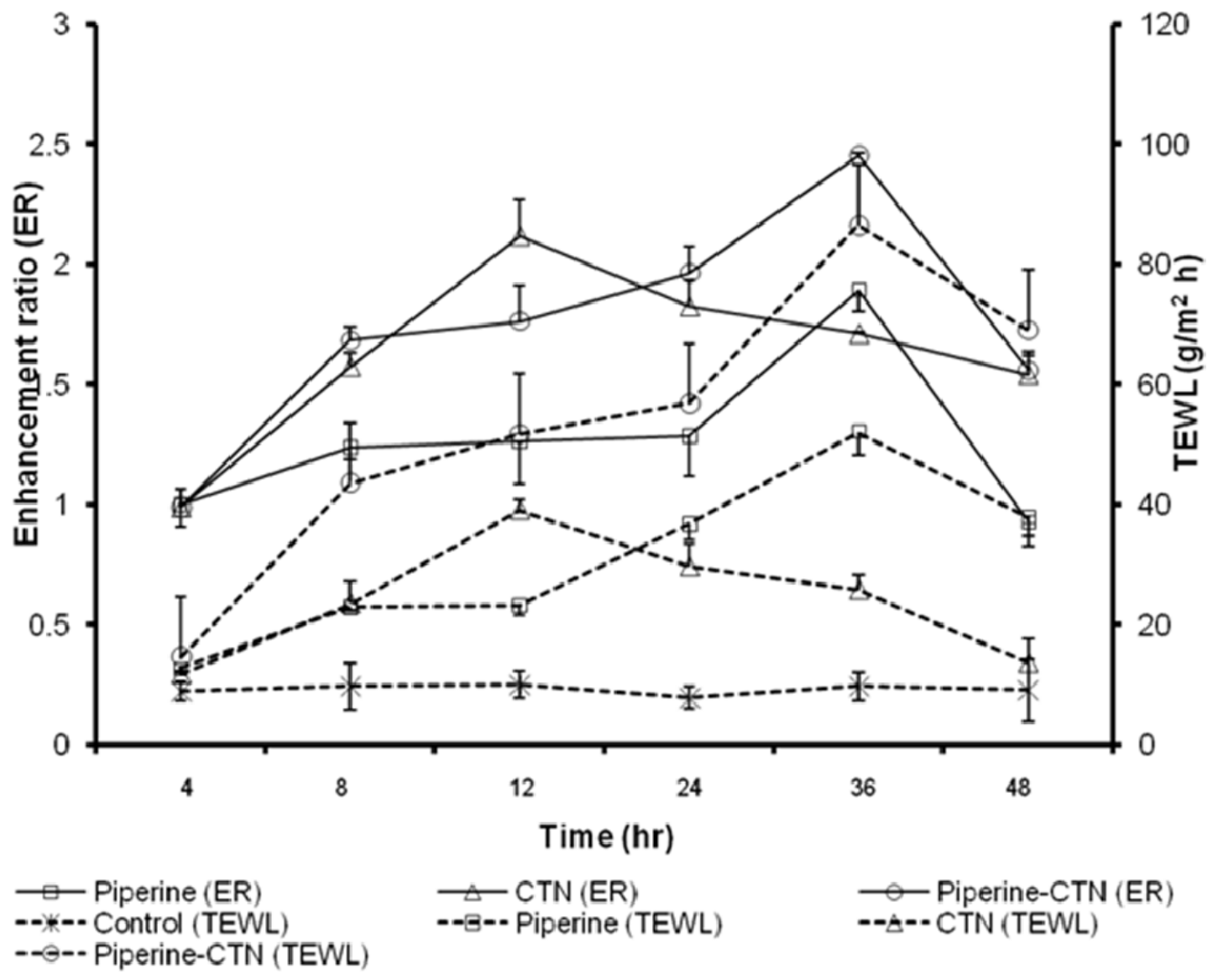

Fig. 4. Enhancement ratio (ER) of RGE and TEWL of viable rat epidermis after treatment with piperine $(0.008 \% \mathrm{w} / \mathrm{v})$, CTN $(1 \% \mathrm{w} / \mathrm{v})$ or piperine $(0.008 \% \mathrm{w} / \mathrm{v})-$ CTN $(1 \% \mathrm{w} / \mathrm{v})$ mixture.

\section{Draize Test}

The results of draize test did not suggest any irritation potential of piperine on rabbit skin.

\section{Pharmacokinetic evaluation of transdermal patches of RGE}

Fig. 5 shows the plasma profile of RGE after oral and transdermal administration to rats. The maximum drug concentration $\left(\mathrm{C}_{\max }\right)$ after administration of tablets containing $0.5 \mathrm{mg}$ of RGE was $17.96 \mathrm{ng} / \mathrm{ml}$ while the time taken to produce this concentration $\left(T_{\max }\right)$ was 1 hr. Transdermal patch containing piperine (patch A) produced 1.7-fold higher $\mathrm{C}_{\max }(29.76$ $\mathrm{ng} / \mathrm{ml}$ ) of RGE as compared to its oral administration. The $C_{\max }$ of RGE was further increased to 2.3 -fold $(40.84 \mathrm{ng} / \mathrm{ml})$ after application of transdermal patch containing piperine-CTN mixture (patch B). The minimum effective concentration reported for human beings after an oral dose of $2 \mathrm{mg}$ of RGE is $27.74 \mathrm{ng} / \mathrm{ml}$ [30]. It is important to note that this concentration was not achieved after oral administration of RGE tablets to rats in the present investigation. This could be due to the administration of lower oral dose of $0.5 \mathrm{mg}$ (1 $\mathrm{\mu g} / \mathrm{g}$ body weight) of RGE [31] to rats. The rate of systemic delivery of RGE across rat skin from transdermal patch containing piperine or piperine-CTN mixture was almost comparable till $6 \mathrm{hr}$. However, after $6 \mathrm{hr}$, the plasma RGE concentration rose at a faster 
rate in rats receiving application of patches containing piperine-CTN mixture as compared to those receiving piperine as enhancer. Although, the $T_{\max }$ in rat plasma was same (36 hr), the $C_{\max }$ was significantly higher $(p<0.05)$ in the former case as compared to the later. In addition, the plasma RGE concentration was maintained significantly higher ( $p<$ 0.05 ) till the end of the study after application of transdermal patches containing piperineCTN mixture as compared to piperine as enhancer. The bioavailability of RGE in rats as judged by the area under the curve was increased to, respectively, 8-fold and 9.5-fold, after application of transdermal patch containing piperine or piperine-CTN mixture in comparison to oral administration of tablets.

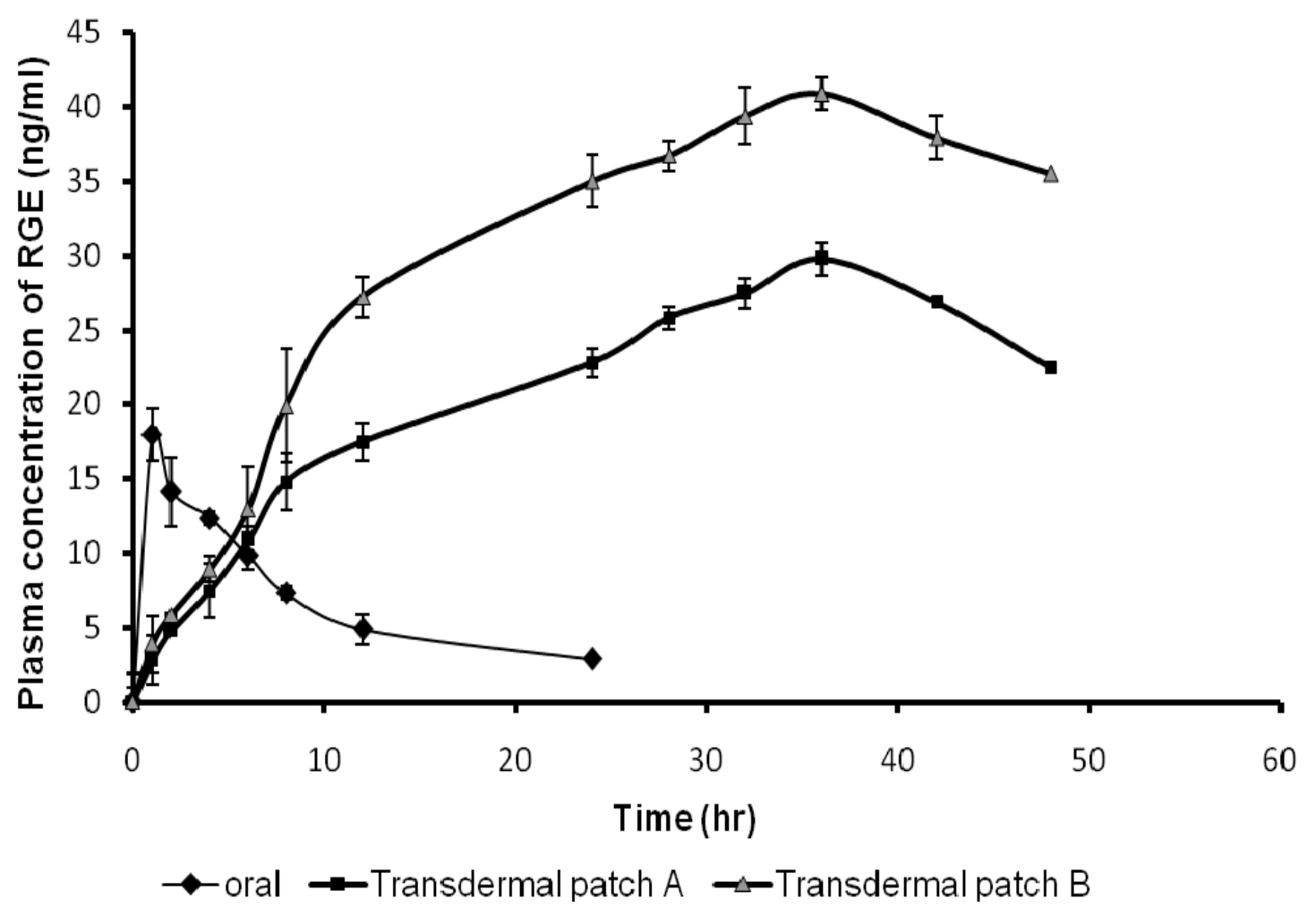

Fig. 5. Pharmacokinetic profile of RGE after oral administration of tablets $(0.5 \mathrm{mg})$ and transdermal formulations.

\section{Conclusions}

It seems pertinent to compare the influence of piperine and piperine-CTN mixture on in vitro permeation, ultrastructural alterations and in vitro transcutaneous delivery of RGE in order to summarize the findings. It was evident from the SEM / TEM studies that piperineCTN mixture was more effective than piperine in altering the ultrastructural features of rat epidermis and this was manifested in the TEWL. The immunofluorescence of HaCaT cells treated with piperine-CTN mixture also indicated greater effect on ZO-1 protein as compared to treatment with piperine alone. However, the magnitude of the effect of piperine-CTN mixture observed in these studies was not reflected in the in vitro permeation enhancement of RGE across excised rat epidermis. The in vitro permeation of RGE using piperine-CTN mixture as enhancer was only 1.6-fold as compared to that in presence of piperine. Similarly, transdermal patches containing piperine-CTN mixture 
were found to perform marginally ( $\sim 9.5$-fold increase) better than piperine containing patches ( 8 -fold increase) as compared to oral administration in enhancing the bioavailability of RGE in rats. However, the piperine-CTN mixture containing patch was observed to maintain the concentration of RGE significantly higher $(p<0.05)$ than that produced by piperine till the end of the study. Hence, it can be inferred that the permeation enhancing effect of piperine was sustained for longer duration but only marginally intensified by CTN. Overall, these findings suggested perturbation of skin lipids and proteins by piperine as well as piperine-CTN mixture to be responsible for enhancing the percutaneous permeation of RGE in rats. However, further investigations using hydrophilic drugs are advocated before suggesting their use as an effective permeation enhancer system in transdermal formulations.

\section{Experimental}

\section{Materials}

RGE was obtained from Torrent Pharmaceuticals, Ahmadabad, India as gift sample. CTN (85\% deacetylation) was a gift sample from Indian Fisheries Institute, Coachin, India. Skin for the in vitro permeation and thermotropic investigations was obtained from Wistar rats $(190-210 \mathrm{~g})$ of either sex. Skin irritation test was performed on male rabbits $(1.2-2.5 \mathrm{Kg})$. All chemicals used in this study were of AR grade.

\section{Methods}

\section{Extraction of Piperine}

Piperine was extracted from the powdered dried fruits of Piper nigrum using the methodology described by Ikan [14]. Purification was done by recrystallization in alcoholic $\mathrm{KOH}(10 \%)$ solution. IR spectroscopy and HPTLC analysis were done for characterizing the purified sample of piperine.

\section{Permeation experiments}

\section{(A) Preparation of epidermal skin}

Freshly obtained epidermal skin was used in all experiments. Hairs on dorsal skin of rat were removed with mechanical clipper followed by shaving with electric razor. The whole skin was soaked in water at $60^{\circ} \mathrm{C}$ for $45 \mathrm{sec}$, followed by careful removal of dermis by gentle scrapping to obtain epidermal sheet [32].

(B) In vitro permeation of RGE:

Across excised rat epidermis in the presence of different donor formulations:

Freshly obtained epidermal sheets were mounted between the donor and receptor compartments of vertical Franz glass diffusion cells. The epidermal sheet was equilibrated for $4 \mathrm{hr}$ using phosphate buffer $\mathrm{pH} 7.4$ (PB) in receptor compartment. The equilibration was judged to be completed when the fluid contained in receptor compartment (phosphate buffer $\mathrm{pH}$ 7.4) did not exhibit any absorbance at $243 \mathrm{~nm}$ on being analyzed spectrophotometrically. The receptor compartment was filled with fresh PB $(\mathrm{pH} 7.4)$ containing sodium azide $(0.05 \% \mathrm{w} / \mathrm{v})$ as preservative and polyethylene glycol $400(P E G)(10 \% \mathrm{v} / \mathrm{v})$ as solubilizing agent. The donor compartment was loaded with dispersion of RGE (2 mg) in PG: EtOH (7:3) mixture, dispersion of RGE $(2 \mathrm{mg})$ and piperine $(0.002-0.01 \% \mathrm{w} / \mathrm{v})$ in PG: 
ETOH (7:3) mixture or dispersion of RGE $(2 \mathrm{mg})$ in CTN solution $(0.5-2 \% \mathrm{w} / \mathrm{v})$ prepared in acetate buffer $\mathrm{pH}$ 6.0. Similarly, permeation studies using best concentration of piperine $(0.008 \% \mathrm{w} / \mathrm{v})$ and chitosan $(1 \% \mathrm{w} / \mathrm{v})$ were carried out. The donor compartment was sealed using a parafilm. Samples from the receptor fluid were withdrawn at different time intervals through $48 \mathrm{hr}$ and immediately analyzed spectrophotometrically at $243 \mathrm{~nm}$ (Beckman, USA, DU 640B). A standard plot of RGE solution prepared in PB containing sodium azide $(0.05 \% \mathrm{w} / \mathrm{v})$ and PEG $400(10 \% \mathrm{v} / \mathrm{v})$ was obtained at $243 \mathrm{~nm}$.

Across rat epidermis excised after treatment of viable skin with different formulations:

Two patches $\left(7 \mathrm{~cm}^{2}\right)$ were prepared on dorsal side of Wistar rats by shaving with mechanical clipper. The patches received treatment with selected dose of piperine $(0.008 \% \mathrm{w} / \mathrm{v})$, CTN $(1 \% \mathrm{w} / \mathrm{v})$ or piperine-CTN mixture for different studies. Experiments were carried out in triplicate. Surface area exposed to treatment was kept constant. The animals were sacrificed after $4 \mathrm{hr}, 8 \mathrm{hr}, 12 \mathrm{hr}, 24 \mathrm{hr}, 36 \mathrm{hr}$ or $48 \mathrm{hr}$. The treated skin patches were excised, epidermis separated and used for studying the in vitro permeation of RGE.

The slope of the terminal steady state segment (flux) of the graph plotted between the cumulative amount of RGE permeated Vs. time was determined for each treatment. The enhancement ratio (ER) for permeation of RGE was calculated by dividing the flux obtained in the presence of enhancer with its respective control.

\section{Microscopic studies}

\section{Transmission electron microscopy (TEM)}

Excised epidermal samples treated with piperine $(0.008 \% \mathrm{w} / \mathrm{v})$, CTN $(1 \% \mathrm{w} / \mathrm{v})$ or piperineCTN mixture for $48 \mathrm{hr}$ or viable skin excised after treatment with piperine-CTN mixture for different time intervals ( $4 \mathrm{hr}, 12 \mathrm{hr}, 24 \mathrm{hr}, 36 \mathrm{hr}$ and $48 \mathrm{hr}$ ) were fixed in Karnovosky's fixative [ $2 \%$ paraformaldehyde and $1 \%(\mathrm{w} / \mathrm{v})$ glutaraldehyde in $0.1 \mathrm{M}$ phosphate buffer $(\mathrm{pH}$ $7.4)]$ and processed. Ultra-thin $\left(60-90^{\circ} \mathrm{A}\right)$ sections were cut and double stained with uranyl acetate and lead citrate for TEM observation (Philips, model-301).

\section{Scanning electron microscopy (SEM)}

The method used for the investigations were similar to those reported earlier [33]. Photographs were taken under scanning electron microscope (LEO 435VP).

\section{Differential Scanning Calorimetric (DSC) Analysis}

The skin was excised, adhering fat and visceral debris removed and washed with physiological saline solution. Epidermis was separated and treated with piperine solution $(0.008 \% \mathrm{w} / \mathrm{v})$, CTN $(1 \% \mathrm{w} / \mathrm{v})$ or piperine-CTN mixture for $48 \mathrm{hr}$. After washing, it was dried to get constant weight and then stored in a chamber containing a saturated solution of sodium chloride $\left(75 \% \mathrm{RH}\right.$ at $\left.25^{\circ} \mathrm{C}\right)$ for $3-4$ days prior to DSC [34]. DSC analysis was performed using heating rate of $1^{\circ} \mathrm{C} / \mathrm{min}$ over ambient to $120^{\circ} \mathrm{C}$. All DSC curves were evaluated especially with regard to the phase-transition enthalpies (peak areas) and maximum temperatures $(\mathrm{Tm})$ of lipid phase transitions. The percentage reduction in enthalpy $(\mathrm{H})$ of endothermic transitions $(\mathrm{j} / \mathrm{g})$ was evaluated by using the formula: 


$$
\left[100-\left(\frac{\Delta H \text { of lipid endotherm due to treatment }}{\Delta H \text { of lipid endotherm in untreated epidermis }}\right)\right] \cdot 100
$$

All the experiments were carried out in triplicate.

\section{Solubility Partition coefficient of RGE}

The solubility of RGE was determined in PB or PB containing sodium azide $(0.05 \% \mathrm{w} / \mathrm{v})$ and PEG $400(10 \% \mathrm{v} / \mathrm{v})$ containing different concentrations of piperine $(0.004,0.008$, or $0.01 \% \mathrm{w} / \mathrm{v}$ ). Excess RGE was added and stirred at $37 \pm 2^{\circ} \mathrm{C}$ in shaker incubator for $24 \mathrm{hr}$. The solutions were filtered through G-4 filter and the filtrates were immediately analyzed for RGE at $243 \mathrm{~nm}$ using spectrophotometer. For partition coefficient studies RGE (40mg) was added in $5.0 \mathrm{ml}$ of a mixture of isopropyl myristate (IPM) and PB (1:5). Stirring was done at $37 \pm 2{ }^{\circ} \mathrm{C}$ in shaker incubator for $24 \mathrm{hr}$. The concentration of RGE in phosphate buffer was determined spectrophotometrically at $243 \mathrm{~nm}$. The ratio of amount of RGE in IPM was calculated by difference.

\section{Cells, media and culture conditions}

Human normal skin keratinocyte cell line (HaCaT), provided by Dr. Sudhir Krishna (National Centre for Biological Sciences, Bangalore, India) was maintained in Dulbecco modified eagle medium (DMEM) with 10\% fetal bovine serum (FBS), 100 units $/ \mathrm{ml}$ penicillin and $100 \mu \mathrm{g} / \mathrm{ml}$ streptomycin (Invitrogen life sciences, USA). The FBS for culturing $\mathrm{HaCaT}$ cells was heat inactivated for 30 mins at $55^{\circ} \mathrm{C}$. HaCaT cells were cultivated according to the method described by Brandner [35]. The cells were maintained at $37^{\circ} \mathrm{C}$ in a humified atmosphere with $5 \% \mathrm{CO}_{2}$. Second or third passage $\mathrm{HaCaT}$ cells were plated on coverslips in a 12 well plate at a density of about $5,000 \mathrm{cells} / \mathrm{cm}^{2}$. After overnight incubation at $37^{\circ} \mathrm{C}$ in a humified $5 \% \mathrm{CO}_{2}$ incubator, cells were supplemented with fresh DMEM medium containing $10 \%$ FBS. The cells were incubated untill they were approximately $50-60 \%$ confluent. Cells were made serum free 16-24 hrs prior fixation and treated with solutions containing different concentrations of piperine for $6 \mathrm{hrs}$. Piperine extract $2 \% \mathrm{w} / \mathrm{v}$ was prepared in PG: EtOH (7:3) solution and the solution was sterilized by filtering (Sartolab. vl15, pore size 0.2 lam), followed by serial dilution in DMEM to obtain solutions of 0.002 , $0.004,0.008$ and $0.016 \mu \mathrm{g} / \mathrm{ml}$ of piperine. The $100 \%$ confluent cells in 12 well plate were treated with solutions containing concentrations of piperine. A control without addition of different extracts was also prepared. The cells were cultured under the conditions described above for $6 \mathrm{hr}$. The growth of cells was monitored on an inverted-phase Nikon TMS light microscope. All experiments were repeated three times.

\section{Immunoflourescence}

Fixation was performed by immersing the cells into freshly prepared $4 \%$ paraformaldehyde for 10 minutes. Immediately after fixation, cells were permeabilized with $0.1 \%$ TritonX-100 (sigma) for 5 minutes. Cells were then rinsed with phosphate buffer saline (PBS) for 3 minutes and blocked in $10 \%$ FBS in PBS for $1 \mathrm{hr}$. This was followed by incubation with primary anti-TJP1 (ZO-1) antibody (1:100 dilution) for $2 \mathrm{hr}$ at room temperature (or overnight at $4^{\circ} \mathrm{C}$ ). After three rinses in PBS for 10 minutes each, coverslips were incubated with FITC-conjugated anti rabbit lgG at $10 \mathrm{ug} / \mathrm{ml}$ in PBS containing $2 \%$ FBS for $2 \mathrm{~h}$. Slides were then rinsed three times in PBS and coverslips were mounted in antifade mounting 
medium (Vector laboratories). Nucleus was stained using propidium iodide $(5 \mu \mathrm{g} / \mathrm{ml})$. Control for antibody specificity was prepared by omitting the primary antibody. The control demonstrated minimal or no staining. For microscopic examination, a Zeiss Axioplan fluorescence microscope (Zeiss) equipped with a confocal scanning unit MRC-600 (Biorad) and an argon-Krypton laser were used.

\section{TEWL determination}

Wistar rats (approximately $250 \mathrm{~g}$ ) were anesthetized. The hair of the dorsal skin was shaved with electric clippers. Two patches $\left(7 \mathrm{~cm}^{2}\right)$, one on either side of spinal cord, were prepared by shaving with mechanical clipper and left undisturbed for $24 \mathrm{hr}$. The patch received treatment with selected dose of piperine $(0.008 \% \mathrm{w} / \mathrm{v})$, CTN $(1 \% \mathrm{w} / \mathrm{v})$ or piperine $(0.008 \% \mathrm{w} / \mathrm{v})-\mathrm{CTN}(1 \% \mathrm{w} / \mathrm{v})$ mixture for different studies. The laboratory temperature and humidity were maintained at, respectively, $24^{\circ} \mathrm{C}$ and $50-55 \% \mathrm{RH}$. The control and treatment sites were marked as circular area $\left(\sim 7 \mathrm{~cm}^{2}\right)$ with a felt tip marker on the dorsal surface of the rat. Surface area exposed to treatment was kept constant. TEWL was recorded on each site after $(4 \mathrm{hr}, 8 \mathrm{hr}, 12 \mathrm{hr}, 24 \mathrm{hr}, 36 \mathrm{hr}$ or $48 \mathrm{hr}$ ) after removal of the patch by using Tewameter TM 210 (Courage + Khazaka Electronic GmbH, Koln, Germany). Data was stored and analyzed by the TEWAMETERO computer software. Each experiment was replicated on three skin patches prepared on different rats.

\section{Draize Test}

The study employed albino rabbits $(1.2-2.5 \mathrm{~kg})$ of either sex $(n=5)$ for testing skin irritation. The procedure adopted for this study was in accordance to that described earlier [36]. The area on the back of each rabbit was shaved so as to accommodate two patches each of two square inch area. Patch made from two layers of light gauze was dipped in $2 \mathrm{ml}$ piperine $(0.008 \% \mathrm{w} / \mathrm{v})$ solution prepared in PG: EtOH $(7: 3)$. The animals were immobilized in the special holder during the 24-hour patch exposure. Upon removal of the patches the animals were observed for any sign of erythema or oedema for a period of 72 hours and scored as reported by Mullerdecker [37]. The observations were repeated after 72 hours.

\section{$X$. Evaluation of pharmacokinetic parameters of RGE in animals}

Wistar rats of either sex (230-250g) were used for the bioavailability studies. The animals were selected after superficial examination of the skin surface for abnormalities. The Wistar rats were housed under controlled environmental conditions (temperature, $23 \pm 1{ }^{\circ} \mathrm{C}$; humidity, $55 \pm 5 \%$ ) and fed with a commercial diet with free access to water. About $10 \mathrm{~cm}^{2}$ of skin was shaved on the dorsal side. Rats were observed for 24 hours for any untoward effect of shaving. The rats were divided into 3 groups $(n=6)$. Group I received oral administration of RGE $(0.5 \mathrm{mg})$ after overnight fasting. Group II received application of transdermal patch containing RGE and piperine dispersed in donor vehicle (PG: EtOH) 7:3. Group III received application of transdermal patch containing RGE and piperine $(0.008 \% \mathrm{w} / \mathrm{v})-\mathrm{CTN}(1 \% \mathrm{w} / \mathrm{v})$ mixture dispersed in donor vehicle. Blood sample $(0.3 \mathrm{ml})$ via the post-orbital venous plexus veins was collected in heparinized tubes at 1, 2, 4, 6, 8, $12,24,28,36,42$ and $48 \mathrm{hr}$. The protocol for the study was approved by Animal Ethics Committee of the Department of Pharmaceutical Sciences and Drug Research Punjabi University, Patiala. The blood samples were transferred to a heparinized eppendoff tube, mixed gently, and then centrifuged (4000 rpm, $5 \mathrm{~min}$ ) to obtain $200 \mu$ l plasma, which was kept at $-20^{\circ} \mathrm{C}$ until analysis. The concentration of RGE in the plasma was determined by 
HPLC analysis. The plasma samples $(1 \mathrm{ml})$ were extracted using extraction buffer $(0.1$ $\mathrm{mol} / / \mathrm{l}$ potassium dihydrogen orthophosphate $(\mathrm{KH} 2 \mathrm{PO} 4, \mathrm{pH} 5.9) 1 \mathrm{ml}$, ethylacetate $5 \mathrm{ml}$ and isoamylalcohol $50 \mu \mathrm{l}$. The $\mathrm{pH}$ was adjusted to 7.4 with $\mathrm{NaOH} 2 \mathrm{M}$. The tubes were shaken on a rotater for $10 \mathrm{~min}$. This was followed by centrifugation at $3000 \mathrm{rpm}$ for $30 \mathrm{~min}$. After centrifugation, the ethylacetate phase was transferred into vials and evaporated to dryness under a stream of nitrogen at $45^{\circ} \mathrm{C}$. The dried extract was reconstituted with $70 \mu \mathrm{l}$ of mobile phase, vortex-mixed and transferred to a clean autosampler vial. This solution was injected into the HPLC system [38] for analyzing RGE.

\section{Acknowledgement}

Financial assistance to Ms. Neeraj Kaushal by Lady Tata Memorial Trust, Mumbai for undertaking this study as a part of Ph.D. work is thankfully acknowledged. The authors thankfully acknowledge the help provided by Department of Molecular Reproduction, Development and Genetics, Indian Institute of Science, Bangalore, India for allowing the use of their facilities to carry out work related to HaCaT cells.

\section{Authors' Statements}

\section{Competing Interests}

The authors declare no conflict of interest.

\section{Animal Rights}

The experimental protocol was approved by the Institutional Animal Ethics Committee of the Punjabi University, Patiala, and the care and handling of the animals were in accordance with the National institutes of health guidelines.

\section{References}

[1] Marbury T, Huang WC, Strange P, Lebovitz H.

Repaglinide versus glyburide: a one-year comparison trial.

Diab Res Clin Pract. 1999; 43: 155-166.

doi:10.1016/S0168-8227(99)00002-9

[2] Southwell D, Barry BW.

Penetration enhancers for human skin: mode of action of 2-pyrrolidone and dimethylformamide on partition and diffusion of model compounds water, n-alcohols and caffeine.

J Invest Dermatol. 1983; 80: 507-515.

doi:10.1111/1523-1747.ep12535090

[3] Mathur AK, Khanna SK.

Dermal toxicity due to industrial chemicals.

Skin Pharmacol Appl Skin Physiol. 2002; 15: 147-153. doi:10.1159/000063543

[4] Pattanaik S, Hota D, Prabhakar S, Kharbanda P, Pandhi P.

Effect of piperine on the steady-state pharmacokinetics of phenytoin in patients with epilepsy.

Phytother Res. 2006; 20: 683-686.

doi:10.1002/ptr.1937 
[5] Bano G, Raina RK, Zutshi U, Bedi KL, Johri RK, Sharma SC.

Effect of piperine on bioavailability and pharmacokinetics of propranolol and theophylline in healthy volunteers.

Eur J Clin Pharmacol. 1991; 41: 615-617.

doi:10.1007/BF00314996

[6] Khajuria A, Thusu N, Zutshi U.

Piperine modulates permeability characteristics of intestine by inducing alterations in membrane dynamics: influence on brush border membrane fluidity, ultrastructure and enzyme kinetics.

Phytomedicine. 2002; 9: 224-231. doi:10.1078/0944-7113-00114

[7] McNamara FN, Randall A, Gunthorpe MJ.

Effects of piperine, the pungent component of black pepper, at the human vanilloid receptor (TRPV1). Br J Pharmacol. 2005; 144: 781-790.

doi:10.1038/sj.bjp.0706040

[8] Hayes P, Meadows HJ, Gunthorpe MJ.

Cloning and functional expression of a human orthologue of rat vanilloid receptor-1.

Pain. 2000; 88: 205-215.

doi:10.1016/S0304-3959(00)00353-5

[9] Ward SM, Bayguinov J, Won KJ, Grundy D, Berthoud HR.

Distribution of the vanilloid receptor (VR1) in the gastrointestinal tract.

J Comp Neurol. 2003; 465: 121-235.

doi:10.1002/cne.10801

[10] Denda M, Fuziwara S, Inoue K.

Immunoreactivity of VR1 on epidermal keratinocyte of human skin.

Biochem Biophys Res Commun. 2001; 285: 1250-1252.

doi:10.1006/bbrc.2001.5299

[11] Luessen HL, de Leeuw BJ, Langemeyer MW, de Boer AB, Verhoef JC, Junginger HE.

Mucoadhesive polymers in peroral peptide drug delivery. VI. Carbomer and chitosan improve the intestinal absorption of the peptide drug buserelin in vivo.

Pharm Res. 1996; 13: 1668-1672.

doi:10.1023/A:1016488623022

[12] Illum L, Farraj NF, Davis SS.

Chitosan as a novel nasal delivery system for peptide drugs.

Pharm Res. 1994; 11: 1186-1189.

doi:10.1023/A:1018901302450

[13] Kitajima Y, Eguchi K, Ohno T, Mori S, Yaoita H.

Tight junctions of human keratinocytes in primary culture: a freeze-fracture study.

J Ultrastruct Res. 1993; 8: 309-313.

doi:10.1016/S0022-5320(83)80017-3

[14] Ikan, R; editor.

In: Natural Products: A Laboratory Guide. 2nd ed.

Academic Press: New York. 1991: 233-238.

http://www.erowid.net/archive/rhodium/chemistry/3base/piperonal.pepper/piperine/

IR.analysis.piperine.pepper.pdf

[15] Russo I, Mese PD, Viretto M, Doronzo G, Mattiello L, Trovati M, Giovanni A.

Sodium azide, a bacteriostatic preservative contained in commercially available laboratory reagents, influences the responses of human platelets via the cGMP/PKG/VASP pathway.

Clin Biochem. 2008; 41: 343-349.

doi:10.1016/j.clinbiochem.2007.10.012 
[16] Suresh D, Srinivasan K.

Studies on the in vitro absorption of spice principles -Curcumin, capsaicin and piperine in rat intestines.

Food Chem Toxicol. 2007; 45: 1437-1442.

doi:10.1016/j.fct.2007.02.002

[17] Thanou M, Verhoef JC, Junginger HE.

Oral drug absorption enhancement by chitosan and its derivatives.

Adv Drug Deliv Rev. 2001; 52: 117-126.

doi:10.1016/S0169-409X(01)00231-9

[18] Dodane V, Amin Khan M, Merwin JR.

Effect of chitosan on epithelial permeability and structure.

Int J Pharm. 1999; 182: 21-32.

doi:10.1016/S0378-5173(99)00030-7

[19] Smith J, Wood E, Dornish M.

Effect of chitosan on epithelial cell tight junctions.

Pharm Res. 2004; 21: 43-49.

doi:10.1023/B:PHAM.0000012150.60180.e3

[20] Lee PJ, Ahmada N, Langer R, Mitragotri S, Shastri VP.

Evaluation of chemical enhancers in the transdermal delivery of lidocaine.

Int J Pharm. 2006; 308: 33-39.

doi:10.1016/j.ijpharm.2005.10.027

[21] Yamane MA, Williams AC, Barry BW.

Effects of terpenes and oleic acid as skin penetration enhancers towards 5-fluorouracil as assessed with time; permeation, partitioning and differential scanning calorimetry.

Int J Pharm. 1995; 116: 237-251.

doi:10.1016/0378-5173(94)00312-S

[22] Boulenc X, Breul T, Gautier JC, Saudemon P, Joyeux H, Roques C, Berger Y, Fabre. G.

Sodium lauryl sulphate increases tiludronate paracellular transport using human epithelial Caco-2 monolayers.

Int J of Pharm. 1995; 123: 71-83.

doi:10.1016/0378-5173(95)00041-G

[23] Udata C, Patel J, Pal D, Hejchman E, Cushman M, Mitra AK.

Enhanced transport of a novel anti-HIV agent cosalane and its congeners across human intestinal epithelial (Caco-2) cell monolayers.

Int J Pharm. 2003; 250: 157-168.

doi:10.1016/S0378-5173(02)00523-9

[24] He W, Guo X, Zhang M.

Transdermal permeation enhancement of $\mathrm{N}$-trimethyl chitosan for testosterone.

Int J Pharm. 2008; 356: 82-87.

doi:10.1016/j.ijpharm.2007.12.050

[25] Lapierre LA.

The molecular structure of the tight junction.

Adv Drug Deliv Rev. 2000; 41: 255-264.

doi:10.1016/S0169-409X(00)00045-4

[26] Gao S, Singh J.

Effect of oleic acid/ethanol and oleic acid/propylene glycol on the in vitro percutaneous absorption of 5 -fluorouracil and tamoxifen and the macroscopic barrier property of porcine epidermis.

Int J Pharm.1998; 165: 45-55.

doi:10.1016/S0378-5173(97)00430-4 
[27] Ganem-Quintanar A, Lafforgue C, Falson-Rieg F, Buri P.

Evaluation of the transepidermal permeation of diethylene glycol monoethyl ether and skin water loss. Int J Pharm. 1997; 147: 165-171.

doi:10.1016/S0378-5173(96)04809-0

[28] Silva CL, Pereira JC, Ramalho A, Pais AA, Sousa JJ.

chitosan polyelectrolyte complexes Films based on chitosan polyelectrolyte complexes for skin drug delivery: Development and characterization.

J Memb Sci. 2008; 320: 268-279.

doi:10.1016/j.memsci.2008.04.011

[29] Moghimi HR, Williams AC, Brian W. Barry AW.

A lamellar matrix model for stratum corneum intercellular lipids.l. Characterisation and comparison with stratum corneum intercellular structure.

Int J Pharm. 1996; 131: 103-115.

doi:10.1016/0378-5173(95)04306-3

[30] Van Heiningen PN, Hatorp V, Kramer Nielsen K, Hansen KT, Van Lier JJ, De Merbel NC.

Absorption, metabolism and excretion of a single oral dose of (14)C-repaglinide during repaglinide multiple dosing.

Eur J Clin Pharmacol. 1999; 55: 521-525.

doi:10.1007/s002280050667

[31] Laghmich A, Ladrière L, Malaisse-Lagae F, Malaisse WJ.

Pancreatic islet responsiveness to $D$-glucose after repeated administration of repaglinide.

Eur J Pharmacol. 1998; 348: 265-270.

doi:10.1016/S0014-2999(98)00156-3

[32] Cornwell, P.A., Barry, B.W., Bouwstra, J.A. and Gorris, G.S.

Modes of action of terpene penetration enhancers in human skin: Differential scanning calorimetry, small angle $\mathrm{x}$-ray diffraction and enhancer uptake studies.

Int J Pharm. 1996; 127: 9-26.

doi:10.1016/0378-5173(95)04108-7

[33] Singh, S., Bi, M., Jayaswal, S. B., and Singh, J.

Effect of current density on the iontophoretic permeability of benzyl alcohol and surface characteristics of human epidermis.

Int J Pharm. 1998; 166: 157-166.

doi:10.1016/S0378-5173(98)00045-3

[34] Vaddi HK, Ho PC, Chan SY.

Terpenes in propylene glycol as skin-penetration enhancers: permeation haloperidol, Fourier

transform infrared spectroscopy, and differential scanning calorimetry.

J Pharm Sci. 2002; 91: 1639-1651.

doi:10.1002/jps. 10160

[35] Brandner JM, Kief S, Grund C, Rendl M, Houdek P, Kuhn C.

Organization and formation of the tight junction system in human epidermis and cultured keratinocytes.

Eur J Cell Biol. 2002; 81: 253-263.

doi:10.1078/0171-9335-00244

[36] Kawahara K, Tojo K.

Skin irritation in transdermal drug delivery systems: A strategy for its reduction.

Pharm Res. 2007; 24: 399-408.

doi:10.1007/s11095-006-9165-4

[37] Mullerdecker K., Furstenberger G, Marks F.

Keratinocyte-derived proinflammatory key mediators and cell viability as in vitro parameters of irritancy: A possible alternative to the draize skin irritation test.

Toxicol Appl Pharmacol. 1994; 127: 99-108.

doi:10.1006/taap.1994.1144 
[38] Ruzilawati AB, Wahab MSA, Imran A, Ismail Z, Gana SH.

Method development and validation of repaglinide in human plasma by HPLC and its application in pharmacokinetic studies.

J Pharma Biomed Anal. 2007; 43: 1831-1835.

doi:10.1016/j.jpba.2006.12.010 